10

\title{
Мономеры с высоким показателем преломления на основе акрилоильных производных спироциклических тиоацеталей 4-пиперидона
}

\author{
(C) В.С. Басистый ${ }^{1,2}$, А.Д. Бухтоярова ${ }^{1}$, Е.В. Васильев ${ }^{1}$, В.В. Шелковников ${ }^{1}$ \\ ${ }^{1}$ Новосибирский институт органической химии им. Н.Н. Ворожцова Сибирского отделения РАН, \\ 630090 Новосибирск, Россия \\ ${ }^{2}$ Новосибирский государственный университет, \\ 630090 Новосибирск, Россия \\ e-mail: vev@nioch.nsc.ru
}

Поступила в редакцию 03.12.2017 г.

В окончательной редакции 20.03.2018 г.

Конденсацией дитиолов с 4-пиперидоном в присутствии каталитических количеств кислот Льюиса получены дитиаазоспирогетероциклические производные. Реакцией с хлористым акрилоилом получены акрилоильные дитиаазаспирогетероциклические производные. В результате полимеризации мономеров были получены прозрачные полимерные пленки оптического качества. Измерены показатели преломления для синтезированных мономеров и полимеров, которые находятся в области $n=1.59-1.64$.

DOI: $10.21883 /$ OS.2018.07.46270.285-17

\section{Введение}

Целенаправленный синтез полимеров, обладающих высоким показателем преломления и в то же время являющихся прозрачными в видимом спектральном диапазоне, является актуальной задачей. Полимеры с высоким показателем преломления находят свое применение в оптоэлектронных изделиях, таких как подложки для дисплеев [1], оптические герметики для OLED [2,3], просветляющие покрытия для оптических компонентов [4], в качестве материала для линз [5], в том числе офтальмологических [6,7], для фоторезистов 193-нм литографии [8] и микролинз в устройствах с зарядовой связью (CCD) или металлооксидных полупроводниковых (CMOS) датчиков изображения (CIS) [9]. Для получения полимеров необходимы мономеры, обладающие высоким показателем преломления. Акрильные мономеры широко используются в реакции свободнорадикальной полимеризации и позволяют формировать полимерные пленки как при термическом, так и при фотохимическом инициировании при действии УФ света.

Известно, что серосодержащие соединения применяются в оптике, требующей высоких показателей преломления [10,11]. Показатель преломления контролируется содержанием серы в материале. Например, мономер $\mathrm{N}$-акрилоилморфолин (1) имеет показатель преломления 1.508 , в то время как его серосодержащий аналог - $\mathrm{N}$-акрилоилтиоморфолин (2) имеет показатель преломления 1.5602 [12]. Показатель преломления также тесно связан с плотностью материала. Введение двух и более атомов серы приводит к существенному увеличению молекулярной рефракции [13] и, как следствие, к увеличению коэффициента преломления.<smiles>C=CC(=O)N1CCOCC1</smiles><smiles>C=CC(=O)N1CCSCC1</smiles>

Соединения серы с алкильными связями стабильны, оптически прозрачны и могут быть использованы для линз, призм, оптических волноводов и в голографических фотополимерных материалах [14-22]. 1,3-дитиоциклические молекулы (S,S-ацетали) образуют важный класс защиты карбонильной функции в химических процессах. В общем случае S,S-ацетали получают конденсацией карбонильных соединений с тиолами или дитиолами, катализируемой протонными кислотами Льюиса. Синтез акриламидных производных, содержащих дитиоспироциклический фрагмент, не описан и оптические свойства таких соединений не исследованы.

Целью работы являлся синтез акриламидных мономеров на основе спироциклических тиоацеталей пиперидона, исследование показателей преломления ряда мономеров, а также полимеров, полученных в результате полимеризации этих мономеров.

\section{Экспериментальная часть}

\section{Получение дитиаазаспироалканов}

Известно, что 1,4-дитиа-8-азаспиро[4.5]декан (4a) получают взаимодействием гидрохлорида 4,4-дигидрокси- 
пиперидина (моногидрат гидрохлорида 4-пиперидона) с 1,2-этандитиолом в толуоле, в качестве катализатора Льюиса используют $n$-толуолсульфокислоту [23,24]. Для синтеза 1,5-дитиа-9-азаспиро[5.5]-ундекана используют в качестве катализатора полифосфорную кислоту [25].

С целью получения серосодержащих акрилатов нами было проведено взаимодействие моногидрата гидрохлорида 4-пиперидона с 1,2-дитиолами (3a-c) и 1,3-дитиолом (3d) в кипящем толуоле, содержащем $n$-толуолсульфокислоту ( $p$-TsOH). В этих условиях получали 1,4-дитиа-8-азаспиро[4.5]деканы (4a-c) с выходом 50-77\%, a c 1,3-пропандитиолом (3d) получается 1,5-дитиа-9-азаспиро[5.5]-ундекан (4d) с выходом 98\% (75\% в $[25])$

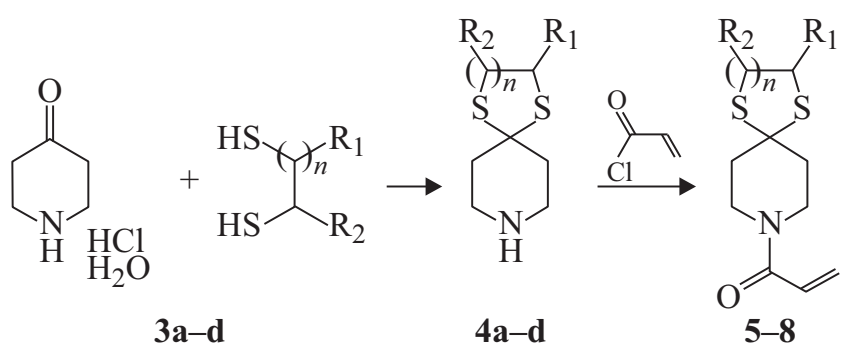

$$
\begin{aligned}
& \mathrm{R}_{1}=\mathrm{R}_{2}=\mathrm{H}, n=1(\mathbf{3 a}, \mathbf{4 a}, \mathbf{5}) \\
& \mathrm{R}_{1}=\mathrm{H}, \mathrm{R}_{2}=\mathrm{CH}_{3}, n=1(\mathbf{3 b}, \mathbf{4 b}, \mathbf{6}) \\
& \mathrm{R}_{1}=\mathrm{R}_{2}=\mathrm{CH}_{3}, n=1(\mathbf{3 c}, \mathbf{4 c}, \mathbf{7}) \\
& \mathrm{R}_{1}=\mathrm{R}_{2}=\mathrm{H}, n=2(\mathbf{3 d}, \mathbf{4 d}, \mathbf{8})
\end{aligned}
$$

Акрильные производные 5-8 получены взаимодействием соединений $\mathbf{4 a - d}$ с хлористым акрилоилом в хлористом метилене с высоким выходом (70-91\%). Строение соединений доказано методами ЯМР-спектроскопии, масс-спектроскопии высокого разрешения, ИК спектроскопии.

$\mathrm{N}$-акрилоилморфолин (1) и $\mathrm{N}$-акрилоилтиоморфолин (2) синтезированы по [26], 1-акрилоилпиперидин4-он (9) по [27], 1-(1,4-диокси-8-азаспиро[4.5]декана-8ил)проп-2-ен-1-он (10) по [28]. Для сравнительного анализа влияния структуры мономера на некоторые его свойства использовались соединения 9 и 10. Данные соединения имеют структуры, подобные исследуемым соединениям 5-8.

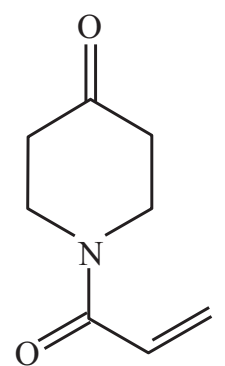

9

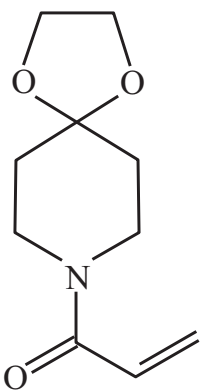

10
Общая методика получения 1,4-дитиа-8-азаспиро[4.5]деканов (4a-c) и 1,5-дитиа-9-азаспиро[5.5]ундекана (4d). $0.01 \mathrm{~mol}$ 1,2-дитиолов 3a-c и 1,3-дитиола 3d добавляли к смеси $0.01 \mathrm{~mol}$ моногидрата гидрохлорида 4-пиперидона и $0.03 \mathrm{~g}$ р-толуолсульфокислоты в $60 \mathrm{~mL}$ толуола. Реакционную смесь кипятили с насадкой ДинаСтарка до прекращения отгонки воды. Смесь охлаждали до комнатной температуры, отгоняли в вакууме ротационного испарителя. Добавляли хлороформ и промывали насыщенным раствором карбоната калия. Водный слой экстрагировали хлороформом. Объединенные хлороформные вытяжки сушили над хлористым кальцием, отгоняли в вакууме ротационного испарителя.

1,4-Дитиа-8-азаспиро[4.5]декан (4a). Выход 77\%. Спектр ЯМР ${ }^{1} \mathrm{H}, \delta$, м.д.: 2.01 (т, 4H, $\left.2 \mathrm{CH}_{2}, J=5.1\right)$, $2.90\left(\mathrm{~T}, 4 \mathrm{H}, 2 \mathrm{CH}_{2}, J=5.1\right) 3.22\left(\mathrm{c}, 4 \mathrm{H}, 2 \mathrm{CH}_{2}\right)$, 4.30 (уш.с, $1 \mathrm{H}$ ).

2-Метил-1,4-дитиа-8-азаспиро[4.5]декан (4b). Выход 53\%. Спектр ЯМР ${ }^{1} \mathrm{H}, \delta$, м.д.: 1.33 (д, $3 \mathrm{H}, \mathrm{CH}_{3}$, $J=6.6$ ), 1.62 (уш.с, $1 \mathrm{H}, \mathrm{NH}), 1.93$ (т, $2 \mathrm{H}, \mathrm{CH}_{2}, J=5.3$ ), 1.98 (т, 2H, $\mathrm{CH}_{2}, J=5.3$ ), 2.74-2.86 (м, 4H), 2.88 (дд, $1 \mathrm{H}$, $\left.J_{1}=11.8, J_{2}=8.2\right), 3.20$ (дд, $1 \mathrm{H}, J_{1}=11.7, J_{2}=4.6$ ), $3.77(\mathrm{M}, 1 \mathrm{H})$.

2,3-Диметил-1,4-дитиа-8-азаспиро[4.5]декан (4c). Выход 50\%. Спектр ЯМР ${ }^{1} \mathrm{H}, \delta$, м.д.: 1.27 (м, 6Н), 1.62 (уш.с, 1Н), 1.99 (м, 4H), 2.81 (м, 2H), 2.88 (м, 2H), $3.35(\mathrm{M}, 2 \mathrm{H})$.

1,5-Дитиа-9-азаспиро[5.5]ундекан (4d). Выход 98\%. Спектр ЯМР ${ }^{1} \mathrm{H}, \delta$, м.Д.: 1.96 (м, 2Н), 2.29 (м, 4Н), $2.55(\mathrm{M}, 1 \mathrm{H}), 2.77(\mathrm{M}, 4 \mathrm{H}), 3.32(\mathrm{M}, 4 \mathrm{H})$.

Соединения $\mathbf{4 a}-\mathbf{d}$ были использованы для следующей стадии без дальнейшей очистки.

Общая методика синтеза акрилоильных дитиаспироазапрочзводных (5-8), 1-акрилоилпиперидин-4-она (9). В трехгорлую колбу емкостью $500 \mathrm{~mL}$, снабженную механической мешалкой, термометром и капельной воронкой с противодавлением, помещали хлористый метилен $(200 \mathrm{~mL}), 0.08 \mathrm{~mol}$ триэтиламина, $0.076 \mathrm{~mol}$ 1,4-дитиа-8-азаспиро[4.5]деканов 4a-c или 1,5-дитиа-9-азаспиро[5.5]ундекана 4d и охлаждали до $0^{\circ} \mathrm{C}$. При перемешивании и охлаждении добавляли по каплям раствор $0.076 \mathrm{~mol}$ акрилоилхлорида в $50 \mathrm{~mL}$ хлористого метилена в течение $0.5 \mathrm{~h}$ при температуре $0-2^{\circ} \mathrm{C}$. Реакционную смесь перемешивали в течение $1 \mathrm{~h}$ при комнатной температуре, промывали водой до нейтральной реакции среды, органический слой сушили хлористым кальцием, растворитель отгоняли в вакууме ротационного испарителя. Остаток хроматографировали на силикагеле. Элюент $\mathrm{CCl}_{4}: \mathrm{CHCl}_{3}$ (градиент от 0 до $100 \%$ ). Элюенты отгоняли в вакууме ротационного испарителя.

1-(1,4-Дитиа-8-азаспиро[4.5]декана-8-ил)проп-2-ен-1-он (5). Выход 70\%. Т. пл. 84-85 ${ }^{\circ}$, ИК спектр (КВr): $1643(\mathrm{C}=\mathrm{O}), 1604(\mathrm{C}=\mathrm{C})$. Найдено: $229.0589\left[\mathrm{M}^{+}\right]$. $\mathrm{C}_{10} \mathrm{H}_{15} \mathrm{ONS}_{2}$. Вычислено: 229.0590. Спектр ЯМР ${ }^{1} \mathrm{H}$, $\delta$, м.Д.: 2.05 (м, 4H), 3.30 (с, 4H), 3.66 (м, 4H), 5.64 (дд, $1 \mathrm{H}, \mathrm{CH}=\mathrm{CH}_{2}, J_{1}=10.0, J_{2}=2.0$ ), 6.22 (дд, $1 \mathrm{H}$, $\left.\mathrm{CH}=\mathrm{CH}_{2}, J_{1}=17.0, J_{2}=2.0\right), 6.52$ (дд, $1 \mathrm{H}, \mathrm{CH}=\mathrm{CH}_{2}$, $\left.J_{1}=17.0, J_{2}=10.0\right)$. 
1-(2-Метил-1,4-дитиа-8-азаспиро[4.5]декана-8-ил)проп2-ен-1-он (6). Выход 74\%. Т.пл. 53-54 ${ }^{\circ}$. ИК спектр $(\mathrm{KBr}): 1647(\mathrm{C}=\mathrm{O}), 1612(\mathrm{C}=\mathrm{C})$. Найдено: 243.0749 . $\left[\mathrm{M}^{+}\right]$. $\mathrm{C}_{11} \mathrm{H}_{17} \mathrm{ONS}_{2}$. Вычислено: 243.0746. Спектр ЯМР ${ }^{1} \mathrm{H}, \delta$, м.д.: 1.41 (д, 3Н, $J_{1}=6.6$ ), 2.04 (дд, 2Н, $\left.J_{1}=6.7, J_{2}=4.2\right), 2.09(\mathrm{~T}, 2 \mathrm{H}, J=5.6), 2.99(\mathrm{M}, 1 \mathrm{H})$, 3.30 (дд, $\left.1 \mathrm{H}, J_{1}=11.8, J_{2}=4.3\right), 3.5-3.8(\mathrm{M}, 4 \mathrm{H})$, $3.89(\mathrm{M}, 1 \mathrm{H}), \quad 5.65$ (дд, $1 \mathrm{H}, \quad \mathrm{CH}=\mathrm{CH}_{2}, \quad J_{1}=10.7$, $J_{2}=1.9$ ), 6.22 (дд, $1 \mathrm{H}, \mathrm{CH}=\mathrm{CH}_{2}, J_{1}=16.8, J_{2}=1.9$ ), 6.52 (дд, $1 \mathrm{H}, \mathrm{CH}=\mathrm{CH}_{2}, J_{1}=16.8, J_{2}=10.7$ ).

1-(2, 3-диметил-1, 4-дитиа-8-азаспиро[4. 5] декана-8-ил)проп-2-ен-1-он (7). Выход 82\%. ИК спектр (КВr): $1645(\mathrm{C}=\mathrm{O}), 1610 \quad(\mathrm{C}=\mathrm{C})$. Найдено: 257.0898. $\left[\mathrm{M}^{+}\right]$. $\mathrm{C}_{12} \mathrm{H}_{19} \mathrm{ONS}_{2}$ С. Вычислено: 257.0903. Спектр ЯМР ${ }^{1} \mathrm{H}, \delta$, м.д.: $1.28(\mathrm{M}, 6 \mathrm{H}), 2.02\left(\mathrm{~T}, 4 \mathrm{H}, J_{1}=5.3\right), 3.35(\mathrm{M}, 1 \mathrm{H})$, 3.45-3.78 (м, 5H), 5.61 (дд, $1 \mathrm{H}, \mathrm{CH}=\mathrm{CH}_{2}, J_{1}=10.0$, $J_{2}=2.0$ ), 6.18 (дд, $1 \mathrm{H}, \mathrm{CH}=\mathrm{CH}_{2}, J_{1}=17.0, J_{2}=2.0$ ), 6.49 (дд, $1 \mathrm{H}, \mathrm{CH}=\mathrm{CH}_{2}, J_{1}=17.0, J_{2}=10.0$ ).

1- (1, 5-дитиа-9-азаспиро [5. 5] ундекана-9-ил) проп-2-ен1-он (8). Выход 91\%. Т.пл. 74-75 С. ИК спектр (КВr): $1645(\mathrm{C}=\mathrm{O}), 1610(\mathrm{C}=\mathrm{C})$. Найдено: 243.0750. $\left[\mathrm{M}^{+}\right]$. $\mathrm{C}_{11} \mathrm{H}_{17} \mathrm{ONS}_{2}$. Вычислено: 243.0746. Спектр ЯМР ${ }^{1} \mathrm{H}$, $\delta$, м.д.: 1.95 (м, 2H), 2.0 (м, 4H), 2.77 (дд, $4 \mathrm{H}, J_{1}=11.5$, $\left.J_{2}=5.0\right), 3.58\left(\mathrm{~T}, 2 \mathrm{H}, J_{1}=5.5\right), 3.71(\mathrm{~T}, 2 \mathrm{H}, J=5.5)$, 5.61 (дд, $1 \mathrm{H}, \mathrm{CH}=\mathrm{CH}_{2}, J_{1}=10.0, J_{2}=2.0$ ), 6.18 (дд, $1 \mathrm{H}$, $\mathrm{CH}=\mathrm{CH}_{2}, J_{1}=17.0, J_{2}=2.0$ ), 6.50 (дд, $1 \mathrm{H}, \mathrm{CH}=\mathrm{CH}_{2}$, $J_{1}=17.0, J_{2}=10.0$ )

Инфракрасные спектры полученных соединений записаны на приборе Vector 22 в таблетках $\mathrm{KBr}$, спектры ЯМР записаны для растворов веществ в $\mathrm{CDCl}_{3}$ на приборах Bruker AV-300 [частота $300.13\left({ }^{1} \mathrm{H}\right)$ и AV-400 $\left({ }^{1} \mathrm{H}\right) \quad(300.13 \mathrm{MHz})$. Химические сдвиги приведены в m.d., сигнал растворителя (сигнал остаточных протонов ( $\delta_{\mathrm{H}} 7.24$ m.d.) использовали в качестве внутреннего стандарта. Масс-спектры записаны на приборах DFS и Finnigan MAT-8200 (молекулярную массу и состав соединений определяли по точному значению массового числа молекулярного иона).

\section{Методика приготовления полимерных слоев}

Для приготовления полимерных слоев использовался метод получения пленок из расплава [29]. Данный метод позволил относительно легко получить из синтезированных мономеров полимерные слои толщиной 500-800 $\mu \mathrm{m}$, необходимые для измерения показателей преломления. Мономеры нагревались до температуры плавления $85-87^{\circ} \mathrm{C}$ на предметном стекле с последующим растеканием расплава по поверхности стекла. Далее образцы подвергались медленному охлаждению, сопряженному с непрерывным воздействием УФ излучения. Таким образом, в результате полимеризации дитиаазоспироакрилатных мономеров были получены прозрачные полимерные пленки оптического качества. В качестве источника УФ излучения использовалась лампа ПРК-2М. Для нагрева предметных стекол применялась нагревательная плита Heater производства MTI Corporation.

\section{Методика измерения коэффициентов преломления}

Для измерения коэффициентов преломления мономеров и полимеров использовался рефрактометр ИРФ-454 БМ. Рефрактометр способен обеспечить погрешность измерения коэффициента преломления до $5 \cdot 10^{-5}$.

Коэффициенты преломления твердых полимерных пленок измерялись с использованием поляризатора и иммерсионной жидкости ( $\alpha$-бромнафталин, CAS: $\left.90-11-9, n_{D}^{25}=1.6570\right)$. Коэффициенты преломления жидких (вязких) мономеров (соединения $1,2,7$ ) измерялись напрямую согласно методике измерений для ИРФ-454 БМ. Коэффициенты преломления твердых мономеров (соединения 5, 6,8-11) измеряли в растворе хлороформа согласно методике, описанной в [30]. Для верификации результатов измерения в качестве реперного соединения использовали раствор мономера акриламида (11) (CAS: 79-06-1) в воде.

\section{Экспериментальные результаты}

Одним из ключевых параметров, определяющих практическую применимость полимерных материалов, является их прозрачность. На рис. 1 приведены спектральные кривые коэффициента экстинкции синтезированных мономеров в ближнем УФ и видимом диапазонах спектра. На рис. 2 представлен спектр поглощения полимерной пленки, полученной из мономера 7. Спектры поглощения полимерных пленок, полученных из мономеров 5,6 и 8 (рис. 1), практически идентичны спектру поглощения, приведенному на рис. 2. Из спектров поглощения синтезированных мономеров и полученных полимеров можно видеть, что во всем видимом диапазоне спектра 400-800 nm соединения обладают высокой прозрачностью.

Для сравнительного анализа влияния структуры мономера, а также для верификации методики измерения коэффициента преломления сыпучих мономеров использовали известный мономер акриламид (11).<smiles>C=CC(N)=O</smiles>

Важным параметром, определяющим применимость соединения в оптике, является его показатель преломления. Были измерены коэффициенты преломления мономеров 1, 2,5-11, а также коэффициенты преломления полимерных пленок, полученных из соединений 5-8. 
Таблица 1. Значения показателей преломления исследованных соединений

\begin{tabular}{|c|c|c|c|c|}
\hline \multirow[b]{2}{*}{ Шифр } & \multirow[b]{2}{*}{ Название } & \multicolumn{3}{|c|}{$n_{D}^{25}$} \\
\hline & & $\begin{array}{c}\text { мономер } \\
\text { измеренный }\end{array}$ & $\begin{array}{c}\text { полимер } \\
\text { измеренный }\end{array}$ & мономер \\
\hline 1 & $\mathrm{~N}$-акрилоилморфолин & $1.5086 \pm 0.0006$ & - & $\begin{array}{l}1.508[12] \\
1.512[32]\end{array}$ \\
\hline 2 & $\mathrm{~N}$-акрилоилтиоморфолин & $1.5608 \pm 0.0002$ & - & $1.5602[12]$ \\
\hline 5 & 1-(1,4-дитиа-8-азаспиро[4.5]декана-8-ил)проп-2-ен-1-он & $1.637 \pm 0.004$ & $1.6396 \pm 0.0008$ & - \\
\hline 6 & 1-(2-метил-1,4-дитиа-8-азаспиро[4.5]декана-8-ил)проп-2-ен-1-он & $1.611 \pm 0.007$ & $1.619 \pm 0.002$ & - \\
\hline 7 & 1-(2,3-диметил-1,4-дитиа-8-азаспиро[4.5]декана-8-ил)проп-2-ен-1-он & $1.594 \pm 0.008$ & $1.5901 \pm 0.0014$ & - \\
\hline 8 & 1-(1,5-дитиа-9-азаспиро [5.5]ундекана-9-ил)проп-2-ен-1-он & $1.640 \pm 0.005$ & $1.6380 \pm 0.0002$ & - \\
\hline 9 & 1-акрилоилпиперидин-4-он & $1.5249 \pm 0.0002$ & - & - \\
\hline 10 & 1-(1,4-диокси-8-азаспиро[4.5]декана-8-ил)проп-2-ен-1-он & $1.5125 \pm 0.0001$ & - & - \\
\hline 11 & Акриламид & $1.498 \pm 0.003$ & - & $1.46[31]$ \\
\hline
\end{tabular}

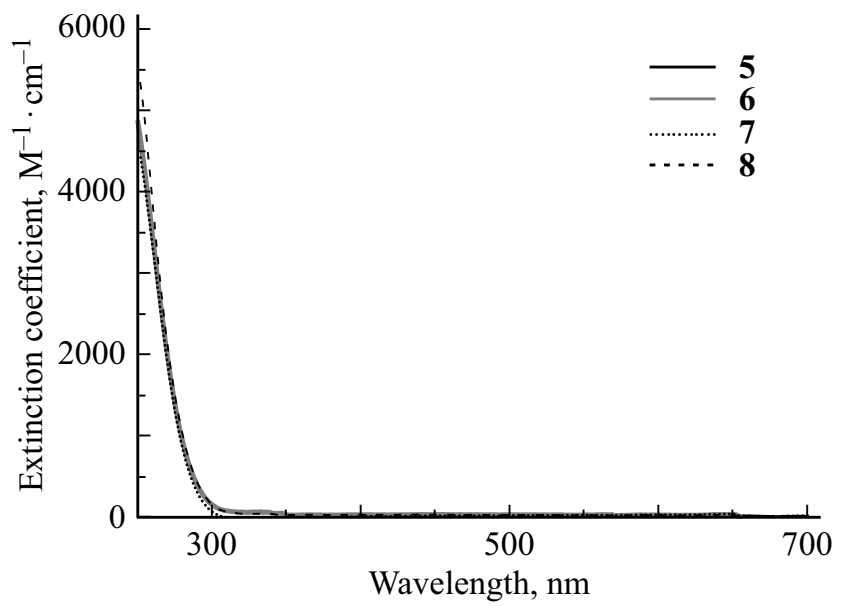

Рис. 1. Спектральные кривые коэффициента экстинкции растворов синтезированных мономеров в хлороформе.

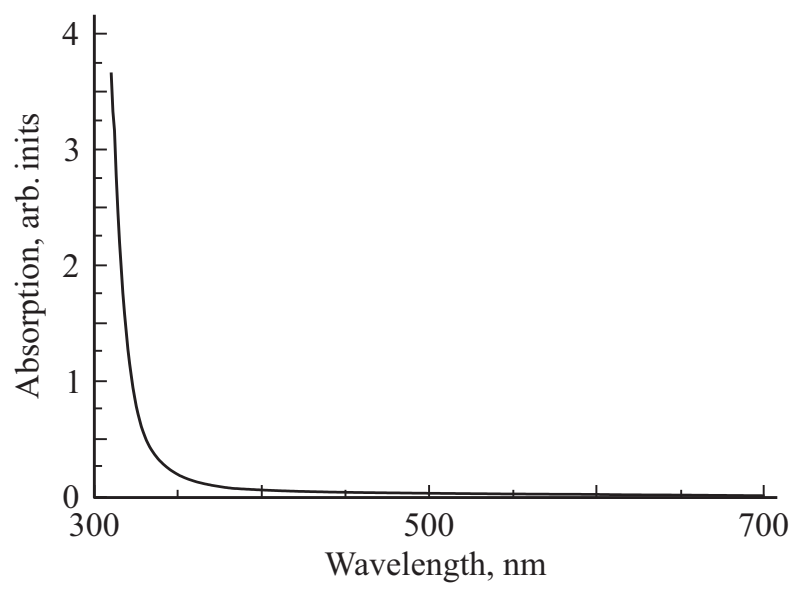

Pис. 2. Спектр поглощения полимерной пленки, полученной из мономера 7 на стеклянной подложке.

Значения показателей преломления, измеренные экспериментально и известные из литературных данных, приведены в табл. 1.
Таблица 2. Значения атомных рефракций по Эйнзенлору и Фогелю

\begin{tabular}{l|l}
\hline Атомы и особенности структуры & $R_{M}, \mathrm{~cm}^{3} / \mathrm{mol}$ \\
\hline H & $1.1[33]$ \\
C & $2.418[33]$ \\
Двойная связь $(\mathrm{C}=\mathrm{C})$ & $1.733[33]$ \\
$\mathrm{O}$ (в карбонильной группе) & $1.7956[34]$ \\
$\mathrm{O}$ (в эфирной группе) & $1.764[33]$ \\
N (в первичных амидах) & $2.65[35]$ \\
N (в третичных амидах) & $2.71[35]$ \\
$\mathrm{S}$ (в тиолах) & $7.69[33]$
\end{tabular}

Как известно, коэффициенты преломления соединений связаны с плотностью вещества и его молярной рефракцией уравнением Лорентц-Лоренца [30]

$$
\frac{R_{M} \rho}{M}=\frac{n^{2}-1}{n^{2}+2},
$$

где $R_{M}$ - молекулярная рефракция, $\rho-$ плотность вещества, $M$ - молекулярная масса, $n-$ коэффициент преломления вещества. С целью определения влияния структуры молекулы на коэффициент преломления мономеров был проведен его расчет на основании значений атомных рефракций по Эйнзенлору и Фогелю, приведенных в табл. 2.

На примере акриламида $(\mathbf{1 1})$, исходя из его структуры и плотности $\rho_{\text {лит }}=1.12 \mathrm{~g} / \mathrm{cm}^{3}$ [31], можно оценить значение коэффициента преломления как $n_{\text {расч }}=1.509$, что близко к измеренному значению $n=1.498$. Аналогичным образом, используя литературные данные о плотности $\mathrm{N}$-акрилоилморфолина (1) $\rho_{\text {лит }}=$ $=1.122 \mathrm{~g} / \mathrm{cm}^{3} \quad[12,32]$, можно оценить значение коэффициента преломления как $n_{\text {расч }}=1.5004$, что близко к измеренному значению $n=1.5086$. Кроме того, были измерены значения плотности мономеров $\mathrm{N}$-акрилоилтиоморфолина (2) и 1-(2,3-диметил-1,4-дитиа-8-азаспиро[4.5]декана-8-ил)проп-2-ен-1-она (7), которые 
Таблица 3. Значения показателей преломления оптических полимеров

\begin{tabular}{l|l}
\hline \multicolumn{1}{c|}{ Полимер } & \multicolumn{1}{c}{$n$} \\
\hline Полиметилметакрилат (РММА) & $1.49[36]$ \\
Бисфенола А поликарбонат (BPA-PC) & $1.58-1.59[37]$ \\
Полистирол (PS) & $1.59[37]$ \\
Сополимер метилметакрилата и стирола (MS) & $1.52-1.54[37]$ \\
Сополимер стирола и акрилонитрила (SAN) & $1.57[38]$ \\
Поли(4-метилпентен-1) (TPX) & $1.46[39]$ \\
Полициклоолефин (COP) & $1.5-1.54[40]$ \\
Политиоуретан (PTU) & $1.52-1.57[41]$
\end{tabular}

соответственно составили $\rho_{(\mathbf{2})}=1.166 \pm 0.004 \mathrm{~g} / \mathrm{cm}^{3}$ $\left(\rho_{\text {лит (2) }}=1.165 \mathrm{~g} / \mathrm{cm}^{3}[12]\right)$ и $\rho_{(7)}=1.242 \pm 0.004 \mathrm{~g} / \mathrm{cm}^{3}$. Соответственно для этих соединений расчетные значения коэффициентов преломления составили $n_{\text {расч(2) }}=1.5499 \quad$ и $\quad n_{\text {расч(7) }}=1.6064, \quad$ а измеренные $n_{(2)}=1.5608$ и $n_{(7)}=1.594$, что также показывает хорошее совпадение расчетных и измеренных данных.

Учитывая, что для соединений 5,6,8-10 затруднительно измерить точные значения плотностей ввиду их порошкообразного состояния, с помощью формулы (1) были рассчитаны их плотности: $\rho_{\text {расч(5) }}=$ $=1.322 \mathrm{~g} / \mathrm{cm}^{3}, \rho_{\text {расч}(6)}=1.262 \mathrm{~g} / \mathrm{cm}^{3}, \rho_{\text {расч }(8)}=1.31 \mathrm{~g} / \mathrm{cm}^{3}$, $\rho_{\text {расч }(9)}=1.189 \mathrm{~g} / \mathrm{cm}^{3}, \rho_{\text {расч}(\mathbf{1 0})}=1.174 \mathrm{~g} / \mathrm{cm}^{3}$.

Исходя из полученных данных, можно сделать вывод о кратном увеличении показателя преломления при замещении кислорода серой на $\sim 0.05$ для пары $\mathbf{1} \rightarrow \mathbf{2}$ и на $\sim 0.12$ для пары $\mathbf{1 0} \rightarrow \mathbf{5}$. Изменение структуры молекулы в результате введения в циклическую ее часть атомов углерода, не образующих $\pi$-сопряженную структуру, существенно не увеличивает показатель преломления. Это видно при сравнении акриламида (11) с $\mathrm{N}$-акрилоилморфолином $(\mathbf{1})\left(\rho \approx 1.12 \mathrm{~g} / \mathrm{cm}^{3}, n \approx 1.5\right)$ или соединения 5 с соединением $8\left(\rho \approx 1.3 \mathrm{~g} / \mathrm{cm}^{3}\right.$, $n \approx 1.64$ ).

Вместе с тем существенное влияние на показатель преломления оказывает плотность вещества. Так, введение внешних метильных групп в соединение 5 (одна группа - соединение $\mathbf{6}$, две группы - соединение 7) приводит к постепенному падению плотности вещества $\rho_{\text {расч }(5)}=1.322 \mathrm{~g} / \mathrm{cm}^{3}, \quad \rho_{\text {расч(6) }}=1.262 \mathrm{~g} / \mathrm{cm}^{3}$, $\rho_{\text {расч(7) }}=1.2417 \mathrm{~g} / \mathrm{cm}^{3}$ ) и соответственно уменьшению показателя преломления: $n_{(5)}=1.637, n_{(6)}=1.6105$ и $n_{(7)}=1.5936$. Очевидно, что внешние метильные группы препятствуют более плотной упаковке вещества, что в итоге сказывается на значении показателя преломления.

Таким образом, как результаты расчета, так и измеренные значения показателя преломления мономеров позволяют считать, что введение двух атомов серы в циклическую структуру молекулы позволяет увеличить показатель преломления вещества по сравнению с кислородным аналогом с 1.51 (10) до $1.64(\mathbf{8})$.
Значения коэффициентов преломления полимеров, полученных из соединений 5-8, близки к таковым для исходных мономеров и находятся в диапазоне 1.59-1.64. Это заметно больше показателей преломления известных полимеров, используемых при разработке оптических устройств и покрытий. Для сравнения показатели преломления ряда полимеров, применяемых в оптике, приведены в табл. 3.

\section{Заключение}

Впервые синтезирован ряд дитиаазаспироакрилатных мономеров, содержащих в циклической структуре атомы серы и обладающих высокими значениями показателей преломления (до 1.64). Синтезированные мономеры полимеризованы с образованием прозрачных пленок при действии УФ света. Измеренные значения показателей преломления дитиаазаспироакрилатных мономеров, а также полученных из них полимерных пленок находятся в диапазоне 1.594-1.64, что является перспективным для использования этих соединений в элементах полимерной оптики.

Авторы выражают благодарность Химическому исследовательскому центру коллективного пользования СО РАН за проведение спектральных и аналитических измерений.

\section{Список литературы}

[1] Nakamura T., Fujii H., Juni N., Tsutsumi N. // Opt. Rev. 2006. N 13. P. 104.

[2] Mosley D.W., Auld K., Conner D., Gregory J., Liu X.Q., Pedicini A., Thorsen D., Wills M., Khanarian G., Simon E.S. //Proc. SPIE. 2008. V. 6910. P. 691017.

[3] Yen Hung-Ju, Liou Guey-Sheng // J. Mater. Chem. 2010. V. 20. P. 4080.

[4] Krogman K.C., Druffel T., Sunkara M.K. // Nanotechnology. 2005. V. 16. P. 338.

[5] Matsuda T., Funae Y., Yoshida M., Yamamoto T., Takaya T. // J. Appl. Polym. Sci. 2000. V. 76. P. 50.

[6] Mentak K. US Patent 7354980 B1, 2008.

[7] Гилберт Ф. // Современная оптометрия. 2015. № 1(81). C. 20.

[8] Allen R.D., Wallraff G.M., Hofer D.C., Kunz R.R. // IBM Res. Develop. 1997. V. 41. P. 95.

[9] Regolini J.L., Benoit D., Morin P. // Microelectron. Reliab. 2007. V. 47. P. 739.

[10] Liub Jin-Gang, Ueda Mitsuru // J. Mater. Chem. 2009. V. 19. P. 8907.

[11] Macdonald E.K., Shaver M.P. // Polym. Int. 2014. doi 10.1002/pi.4821

[12] Parrod J., Elles J. // J. Polymer Science. 1958. V. 29. P. 411.

[13] Ye Ji-Myoung, Maheswara Muchchintala, Do Jung-Yun // Bull. Korean Chem. Soc. 2012. V. 33. N 8. P. 2494.

[14] You N.H., Higashihara T., Suzuki Y., Ando S., Ueda M. // Polym. Chem. 2010. V. 1. P. 480.

[15] Liu J.G., Ueda M. // J. Mater. Chem. 2009. V. 19. P. 8907. 
[16] Liu L., Zheng Z., Wang X.L. // J. Appl. Polym. Sci. 2010. V. 117. P. 1978.

[17] Liu S.J., Tian L.Y., Zheng Z., Wang X.L. // J. Appl. Polym. Sci. 2009. V. 113. P. 3498.

[18] Nemoto T., Konishi G., Funaoka M. // Polym. J. 2010. V. 42. P. 896.

[19] Okutsu R., Suzuki Y., Ando S., Ueda M. // Macromolecules. 2008. V. 41. P. 6165.

[20] Seto R., Kojima T., Hosokawa K., Koyama Y., Konishi G., Takata T. // Polymer. 2010. V. 51. P. 4744.

[21] Gao C., Yang B., Shen J. // J. Appl. Polym. Sci. 2000. V. 75. P. 1474.

[22] Zhang S.J., Li Y.F., Ma T., Zhao J.J., Xu X.Y., Yang F.C., Xiang X.Y. // Polym. Chem. 2010. N 1. P. 485.

[23] Zenitz B.L. Patent US 4308382 A1, 1981.

[24] Gao Chao, Ye Ting-Hong, Wang Ning-Yu, Zeng Xiu-Xiu, Zhang Li-Dan, Xiong Ying, You Xin-Yu, Xia Yong, Xu Ying, Peng Cui-Ting, Zuo Wei-Qiong, Wei Yuquan, Yu Luo-Ting // Bioorg. Med. Chem. Lett. 2013. V.23. N17. P.4919.

[25] Wang J. // JACS. 2009. V. 131. P. 8066.

[26] Taillades J., Garrel L., Lagriffoul P.H., Commeyras A. // Bull. Soc. Chim. France. 1992. N 2. P. 191.

[27] Mann S., Carillon S., Breyne O., Marquet A. // Chemistry. 2002. V. 8. N 2. P. 439.

[28] Sola R., Brugidou J., Taillades J., Commeyras A., Previero A. // Tetrahedron Lett. 1983. V. 24. N 14. P. 1501.

[29] Григорьев Г.П., Федотова О.Я. Лабораторный практикум по технологии пластических масс. Часть 2. М.: Высшая школа, 1977. $264 \mathrm{c}$.

[30] Иоффе Б.В. Рефрактометрические методы химии. Л.: Химия, 1983. $352 \mathrm{c}$.

[31] Электронный ресурс. Режим доступа: https://pubchem.ncbi.nlm.nih.gov/compound/ /acrylamide\#section=Vapor-Density

[32] Электронный ресурс. Режим доступа: http://www.sigmaaldrich.com/catalog/product/aldrich/ $/ 448273$ ?lang $=$ en $\&$ region $=\mathrm{RU}$

[33] Справочник химика. Т. 1. Л.: Химия, 1966. 1072 с.

[34] Padron J.A., Carrasco R., Pellon R.F. // J. Pharm. Pharmac. Sci. 2002. V. 5. N 3. P. 258.

[35] Dean J.A. In: Lange's Handbook of Chemistry. NY.: McGrawHill, 1999. P. 1265.

[36] Серова В.Н. // Вестник Казанского технологического университета. 2012. Т. 15. N 7.

[37] Смирнова О.В., Ерофеева С.Б. Поликарбонаты. М.: Химия, 1975. $288 \mathrm{c}$.

[38] Серова В.Н. Полимерные оптические материалы. СПб.: Научные основы и технологии. 2011. 384 с.

[39] Электронный ресурс. Режим доступа: http://www.mitsuichemicals.com/tpx_cha.htm

[40] Электронный ресурс. Режим доступа: http://www.zeon.co.jp/business_e/enterprise/speplast/ /speplast1.html\#h2-3

[41] Электронный ресурс. Режим доступа: http://www.tpu.covestro.com/en/Technologies/Properties/ /Optical-Properties 